\title{
Physical-biological coupling in the coastal upwelling system of the Ría de Vigo (NW Spain). II: In vitro approach
}

\author{
S. Piedracoba ${ }^{1,2, *}$, M. Nieto-Cid ${ }^{1}$, I. G. Teixeira ${ }^{1}$, J. L. Garrido ${ }^{1}$, \\ X. A. Álvarez-Salgado' ${ }^{1}$, G. Rosón ${ }^{2}$, C. G. Castro ${ }^{1}$, F. F. Pérez ${ }^{1}$ \\ ${ }^{1}$ CSIC, Instituto de Investigacións Mariñas, Eduardo Cabello 6, 36208 Vigo, Spain \\ ${ }^{2}$ Facultade de Ciencias do Mar, Universidade de Vigo, Marcosende, 36200 Vigo, Spain
}

\begin{abstract}
The metabolism of the pelagic ecosystem of the Ría de Vigo (NW Spain) was studied during July and September 2002. Measurements of primary production $(P g)$ and respiration $(R)$ were performed at a single site twice a week at 5 depths, from surface to bottom. In July, the net community production ( $\mathrm{NCP}=P g-R$ ) decreased along with $P g$, from 0.73 under strong upwelling to $0.14 \mathrm{~g}$ $\mathrm{N} \mathrm{m}^{-2} \mathrm{~d}^{-1}$ under weak upwelling conditions. In September, NCP increased from -0.10 under downwelling to $0.00 \mathrm{~g} \mathrm{~N} \mathrm{~m}^{-2} \mathrm{~d}^{-1}$ under weak upwelling conditions. Microzooplankton grazing and sedimentation rates were also measured. The high grazing rates observed (58 to $115 \%$ of $P g$ ) raises doubts about the previously assumed efficiency of the ría to transfer phytoplankton biomass directly to the metazoans. Our results suggest that phytoplankton biomass is probably imported from the shelf to support the metabolic requirements of the microheterotrophs in September. A comparison of the metabolic state of the ría derived from these measurements with the geochemical budget generated different results in some cases. Both approaches were complementary and their simultaneous application may offer a better understanding of ecosystem functioning.
\end{abstract}

KEY WORDS: Primary production · Respiration · Grazing · Sedimentation · Upwelling · Downwelling • Rías Baixas (NW Spain)

\section{INTRODUCTION}

This work is the companion paper by Piedracoba et al. (2008, this volume), who evaluated the new production (NP; see Table 1 for list of abbreviations) of the central segment of the coastal upwelling system of the Ría de Vigo at short time-scales $(<4$ d) under dominant upwelling and downwelling conditions with a geochemical inverse method. Although NP rates estimated with the geochemical approach may be directly interpreted at the ecosystem level (Smith \& Hollibaugh 1997), this method does not provide information on the specific biogeochemical processes (production, respiration, sedimentation, grazing, etc.) that lead to a given NP under a particular hydrographic and dynamic scenario. This paper evaluates the variability of different biogeochemical rates using sediment traps and in vitro incubations (net community production and dark res- piration by the oxygen dark/light incubation method, and microzooplankton herbivory by the dilution technique). Then, the fluxes derived from the individual in vitro determinations are summed up to evaluate the metabolic status of the system, compared with the results of the mass balance approach of Piedracoba et al. (2008), and discussed in terms of the strengths and weaknesses of both methods.

\section{MATERIALS AND METHODS}

Stn 00 (Fig. 1) is located in the middle segment of the coastal upwelling system of the Ría de Vigo (water depth, $40 \mathrm{~m}$ ). It was sampled about $1 \mathrm{~h}$ before sunrise on 15, 18, 22 and 26 July and 17, 19, 23 and 26 September 2002 (see Piedracoba et al. 2008 for details). Water samples were taken with a rosette sampler equipped 
with twelve 101 PVC Niskin bottles with stainless-steel internal springs. Salinity and temperature were recorded with an SBE 9/11 CTD probe attached to the rosette sampler. Conductivity measurements were converted into practical salinity scale values with the equation of UNESCO (1985). Water samples for the analyses of the chemical variables and the production/respiration rates were collected from 5 depths: at the surface or at the depth of $50 \%$ of photosynthetically available radiation (PAR) penetration $(2.5 \pm 0.3 \mathrm{~m})$, at $25 \%$ of PAR penetration $(7 \pm 1 \mathrm{~m})$, at $1 \%$ of PAR penetration $(14.2 \pm 2.2 \mathrm{~m})$, at $26.2 \pm 1.2 \mathrm{~m}$, and at the bottom. Microzooplankton grazing experiments were performed only at the surface (50\% PAR).

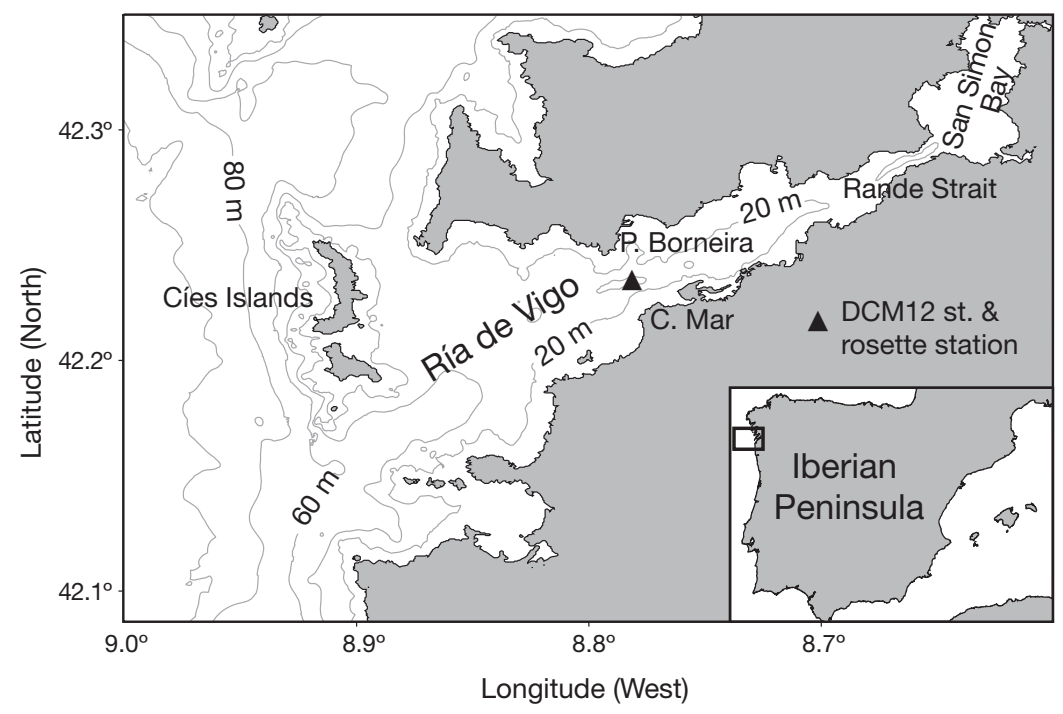

Chemical variables. Salinity $(\mathrm{S}, \mathrm{accu}-$ racy \pm 0.003$)$, dissolved oxygen $\left(\mathrm{O}_{2}, \pm 0.5 \mu \mathrm{mol} \mathrm{kg}{ }^{-1}\right), \mathrm{N}$ nutrient salts $\left(\mathrm{NH}_{4}{ }^{+}, \pm 0.05 \mu \mathrm{M} ; \mathrm{NO}_{2}^{-}, \pm 0.02 \mu \mathrm{M}\right.$; and $\mathrm{NO}_{3}{ }^{-}, \pm 0.1 \mu \mathrm{M}$ ), dissolved organic nitrogen (DON, \pm 0.2 $\mu \mathrm{mol} \mathrm{N} \mathrm{l}^{-1}$ ), particulate organic nitrogen $(\mathrm{PON}, \pm 0.1$ $\mu \mathrm{mol} \mathrm{N} \mathrm{l^{-1 }}$ ), particulate organic carbon $\left(\mathrm{POC}_{,} \pm 0.3 \mu \mathrm{mol}\right.$ $\mathrm{C}^{-1}$ ), particulate organic phosphorus (POP, $\pm 0.02 \mu \mathrm{mol}$

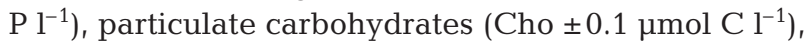
chl a $\left(\mathrm{Chl}, \pm 0.05 \mathrm{mg} \mathrm{m}^{-3}\right)$, and pigments were mea-

Table 1. Glossary of relevant terms

\begin{tabular}{|ll|}
\hline$C_{0}, C_{\mathrm{t}}$ & Initial and final carbon biomass concen- \\
$\mathrm{Chl}_{0}$ & trations \\
$D$ & Initial chlorophyll concentration \\
$\mathrm{Dep}$ & Dilution factor of the sample \\
$g$ & Deposition rate \\
$G$ & Instantaneous grazing mortality rate \\
$k$ & Grazing rate \\
$\mathrm{Lip}$ & Net community growth rate \\
$\mathrm{NCP}$ & Particulate lipids \\
$\mathrm{NEP}$ & Net community production \\
$\mathrm{NEP}$ & Net ecosystem production \\
$(\mathrm{o}-\mathrm{i})_{\mathrm{T}}$ & Net ecosystem production of $\mathrm{N}_{\mathrm{T}}$ \\
$\mathrm{PCho}$ & Net budget of outputs minus inputs of $\mathrm{N}_{\mathrm{T}}$ \\
$P g$ & Particulate carbohydrates \\
$\mathrm{Prt}$ & Gross primary production \\
$\mathrm{Pho}$ & Particulate proteins \\
$\mathrm{POC}, \mathrm{PON}, \mathrm{POP}$ & Particulate phosphorous compounds \\
& Particulate organic carbon, nitrogen and \\
$\mathrm{POM}$ & Particulate organic matter \\
$R$ & Respiration rate \\
$\mathrm{Sed}$ & Sedimentation rate \\
$\mu$ & Instantaneous phytoplankton growth \\
$\omega$ & rate \\
$\Delta\left(\mathrm{V} \cdot \mathrm{N}_{\mathrm{T}}\right) / \Delta t$ & Sedimentation velocity \\
& Accumulation of $\mathrm{N}_{\mathrm{T}}$ \\
& \\
\hline & \\
\hline
\end{tabular}

sured as described elsewhere (Álvarez-Salgado et al. 2005).

Chemical composition of particulate organic matter. Assuming that the changes in the $\mathrm{C} / \mathrm{N} / \mathrm{P}$ ratio of particulate organic matter (POM) are due to variations in the proportions of the major groups of biomolecules rather than in the chemical formula of each group, it is possible to estimate their proportions. Fraga et al. (1998) reviewed the average composition of marine phytoplankton carbohydrates (PCho, $\mathrm{C}_{6} \mathrm{H}_{10} \mathrm{O}_{5}$ ), lipids (Lip, $\mathrm{C}_{53} \mathrm{H}_{89} \mathrm{O}_{6}$ ), proteins (Prt, $\mathrm{C}_{139} \mathrm{H}_{217} \mathrm{O}_{45} \mathrm{~N}_{39} \mathrm{~S}$ ), phosphorus compounds ( $\mathrm{Pho}, \mathrm{C}_{45} \mathrm{H}_{76} \mathrm{O}_{31} \mathrm{~N}_{12} \mathrm{P}_{5}$ ) and pigments ( $\mathrm{Chl}$, $\mathrm{C}_{46} \mathrm{H}_{52} \mathrm{O}_{5} \mathrm{~N}_{4} \mathrm{Mg}$ ). From the chemical formulae of these biomolecules, the following set of 5 linear equations can be written:

$\mathrm{POC}=139 \times \mathrm{Prt}+6 \times \mathrm{PCho}+53 \times \mathrm{Lip}+45 \times \mathrm{Pho}+46 \times \mathrm{Chl}$

$\mathrm{H}=217 \times$ Prt $+10 \times$ PCho $+89 \times$ Lip $+76 \times$ Pho $+52 \times$ Chl

$\mathrm{O}=45 \times \mathrm{Prt}+5 \times \mathrm{PCho}+6 \times \mathrm{Lip}+31 \times \mathrm{Pho}+5 \times \mathrm{Chl}$

$\mathrm{PON}=39 \times \mathrm{Pr}+12 \times \mathrm{Pho}+4 \times \mathrm{Chl}$

$\mathrm{POP}=5 \times \mathrm{Pho}$

Since POC, PON, POP, PCho and Chl were measured, the system can be solved to obtain the 5 unknowns $(\mathrm{H}$, $\mathrm{O}$, Prt, Lip and Pho) and then calculate the average chemical formulae (atoms of $\mathrm{C}, \mathrm{H}, \mathrm{O}, \mathrm{N}$ and $\mathrm{P}$ ) and the proportions $(\mathrm{w} / \mathrm{w})$ of the different biomolecules (PCho, Prt, Lip, Pho and Chl) of each particular sample. The oxidation of these compounds to $\mathrm{CO}_{2}, \mathrm{NO}_{3}^{-}, \mathrm{HPO}_{4}{ }^{2-}$ and $\mathrm{H}_{2} \mathrm{O}$ produce different $\mathrm{Rc}_{\mathrm{C}} \mathrm{Rn}$ and $\mathrm{Rp}$ stoichiometric ratios. 
Metabolic balance of the water column. Daily primary production $(P g)$ and respiration $(R)$ rates of the plankton community were estimated by the oxygen light-dark bottle method (Strickland \& Parsons 1972). Samples collected before sunrise were transferred to black polyethylene carboys, which were gently shaken before sampling to prevent sedimentation of the particulate material. Series of eleven $110 \mathrm{ml}$ Winkler bottles composed of triplicate initial, and quadruplicate light and dark subsamples were filled. Each series of bottles was incubated for $24 \mathrm{~h}$ (starting within $1 \mathrm{~h}$ of sunrise) at the original light and temperature conditions in an incubator. In situ temperature conditions were reproduced in the incubators by mixing the appropriate proportions of cold $\left(10^{\circ} \mathrm{C}\right)$ and warm $\left(30^{\circ} \mathrm{C}\right)$ water supplies and in situ light conditions were simulated using increasing numbers of slides of a $1 \mathrm{~mm}$ mesh. Dissolved oxygen was determined by Winkler potentiometric end point titration.

Microzooplankton herbivory. Four experiments, on 18 and 26 July and 19 and 26 September, were carried out using the dilution technique (Landry \& Hassett 1982). Surface water was collected with a $30 \mathrm{l}$ Niskin bottle dipped twice. Water from the first dip was gravity-filtered through a Gelman Suporcap filter (effective filtration area, $1000 \mathrm{~cm}^{2}$; nominal retention, $0.2 \mu \mathrm{m}$ ) and mixed with unfiltered seawater from the second dip in twelve 2.31 transparent polycarbonate bottles to obtain duplicates of 10,20,40,60, 80 and $100 \%$ of plankton ambient levels. Bottles were completely filled and incubated for $24 \mathrm{~h}$ at the original light and temperature conditions in an incubator placed in the terrace of the base laboratory. Initial and final subsamples were taken from all experimental bottles for the determination of carbon biomass of pico-, nano- and microplankton. For pico- and nanoplankton carbon biomass determination, subsamples of $10 \mathrm{ml}$ fixed with buffered formaldehyde ( $2 \%$ final concentration) and stained with DAPI were filtered through $25 \mathrm{~mm}$ black polycarbonate filters $(0.2 \mu \mathrm{m}$ of pore size) and examined using an epifluorescence Nikon microscope (Porter \& Feig 1980). For microplankton carbon biomass determination, subsamples preserved in Lugol's iodine and sedimented in composite sedimentation chambers were observed through an inverted microscope (Utermöhl 1958). Dimensions of the species or groups identified were measured, and cell volumes were converted to cell carbon according to Strathmann (1967) for diatoms and dinoflagellates, Verity et al. (1992) for flagellates, and Putt \& Stoecker (1989) for ciliates. Changes in carbon biomass concentration were used to estimate the net community growth rate $(k)$ :

$$
k=\frac{1}{t} \cdot\left(\frac{C_{t}}{C_{0}}\right)
$$

where $t$ is the duration of the experiment $(1 \mathrm{~d})$, and $C_{0}$ and $C_{\mathrm{t}}$ are the initial and final carbon biomass concentrations, respectively. Instantaneous growth $(\mu)$ and grazing $(g)$ rates were calculated by the linear regression of the daily net growth rate $(k)$ against the dilution factor $(D)$ :

$$
k=\mu-D \cdot g
$$

In cases of saturated feeding responses, $\mu$ was obtained by the regression of the linear part of the curve and $g$ was calculated by the difference between the net growth rate in the undiluted sample and $\mu$ (Gallegos 1989).

Sedimentation rates. A multitrap collector was deployed at the $1 \%$ PAR, and anchored to the seabed, for about $6 \mathrm{~h}$ on 18 and 22 July and 19 and 26 September. The collector was described in Knauer et al. (1979) following the JGOFS protocols (UNESCO 1994) and consisted of 4 individual multitrap baffled cylinders of $6 \mathrm{~cm}$ diameter and $60 \mathrm{~cm}$ length. Each cylinder was placed at the middle of a PVC cross, and the entire system was designed following Gardner's $(1980 a, b)$ suggestions with respect to aspect ratio, axial geometry of collectors, baffles and mooring configuration, to ensure that the trap was efficient in collecting material for most environmental situations. The design is also adequate for the advective conditions prevailing in the ría. The tidal currents during the study varied from 3 to $10 \mathrm{~cm} \mathrm{~s}^{-1}$ and are in the range reported by Gardner (1980b) for good trap efficiency. Prior to each deployment, the cylinders were filled with a solution of filtered seawater to which $5 \mathrm{~g}$ of $\mathrm{NaCl}$ was added per liter of solution. This solution prevented the exchange of material with the surrounding water. The content of each cylinder was collected on $47 \mathrm{~mm}$ Whatman GF/F filters to determine POC, PON, POP and Chl.

\section{RESULTS}

Six hydrographic periods were defined by Piedracoba et al. (this volume): (i) spin-down of strong summer upwelling (15 to 18 July), (ii) summer relaxation (18 to 22 July), (iii) spin-up of weak summer upwelling (22 to 26 July), (iv) autumn downwelling (17 to 19 September), (v) autumn transition (19 to 23 September), and (vi) autumn upwelling (23 to 26 September).

\section{Chemical composition of the biogenic materials}

The contribution (w/w) of Pho, Prt, PCho, and Lip to the POM of the photic and aphotic layers is shown in Table 2. The proportion of Pho+Prt, i.e. the N\&P compounds, did not change significantly with depth: it 
Table 2. Percentages of phosphorus compounds (Pho), proteins (Prt), lipids (Lip) and carbohydrates (Cho) in the particulate organic material of samples collected at Stn 00. Average composition of the biogenic materials in the upper (photic) and lower (aphotic) layers of the middle segment of the Ría de Vigo in July and September 2002. The stoichiometric ratio of conversion of $\mathrm{O}_{2}$ into organic carbon $\left(\mathrm{Rc}=\frac{\Delta \mathrm{O}_{2}}{\Delta \text { Corg }}\right)$, organic nitrogen $\left(\mathrm{Rn}=\frac{\Delta \mathrm{O}_{2}}{\Delta \text { Norg }}\right)$ and organic phosphorous $\left(\mathrm{Rp}=\frac{\Delta \mathrm{O}_{2}}{\Delta \text { Porg }}\right)$ are provided

\begin{tabular}{|c|c|c|c|c|c|c|c|c|c|c|}
\hline Date & Layer & Pho & Prt & Lip & Cho & Formula & $\mathrm{O}_{2}$ & Rc & $\mathrm{Rn}$ & $\mathrm{Rp}$ \\
\hline $15 \mathrm{Jul}$ & Upper & 19.1 & 46.4 & 18.9 & 15.6 & $\mathrm{C}_{67} \mathrm{H}_{108} \mathrm{O}_{25} \mathrm{~N}_{11} \mathrm{P}$ & 96 & 1.44 & 9.0 & 96 \\
\hline $18 \mathrm{Jul}$ & Upper & 16.2 & 50.4 & 23.8 & 9.6 & $\mathrm{C}_{82} \mathrm{H}_{132} \mathrm{O}_{27} \mathrm{~N}_{13} \mathrm{P}$ & 119 & 1.46 & 9.1 & 119 \\
\hline $22 \mathrm{Jul}$ & Upper & 13.6 & 38.8 & 15.9 & 31.7 & $\mathrm{C}_{91} \mathrm{H}_{148} \mathrm{O}_{40} \mathrm{~N}_{12} \mathrm{P}$ & 125 & 1.37 & 10.3 & 125 \\
\hline $26 \mathrm{Jul}$ & Upper & 13.5 & 49.7 & 14.6 & 22.2 & $\mathrm{C}_{93} \mathrm{H}_{149} \mathrm{O}_{37} \mathrm{~N}_{15} \mathrm{P}$ & 132 & 1.42 & 8.8 & 132 \\
\hline $17 \mathrm{Sep}$ & Upper & 14.1 & 44.6 & 18.9 & 22.4 & $\mathrm{C}_{91} \mathrm{H}_{146} \mathrm{O}_{35} \mathrm{~N}_{13} \mathrm{P}$ & 128 & 1.41 & 9.6 & 128 \\
\hline 19 Sep & Upper & 6.5 & 44.9 & 9.2 & 39.5 & $\mathrm{C}_{189} \mathrm{H}_{303} \mathrm{O}_{90} \mathrm{~N}_{26} \mathrm{P}$ & 254 & 1.35 & 9.7 & 254 \\
\hline 23 Sep & Upper & 13.7 & 38.5 & 10.8 & 36.9 & $\mathrm{C}_{88} \mathrm{H}_{142} \mathrm{O}_{43} \mathrm{~N}_{12} \mathrm{P}$ & 119 & 1.35 & 9.9 & 119 \\
\hline 26 Sep & Upper & 11.7 & 47.5 & 17.1 & 23.6 & $\mathrm{C}_{109} \mathrm{H}_{175} \mathrm{O}_{43} \mathrm{~N}_{16} \mathrm{P}$ & 153 & 1.41 & 9.4 & 153 \\
\hline $15 \mathrm{Jul}$ & Lower & 13.2 & 50.7 & 22.6 & 13.6 & $\mathrm{C}_{100} \mathrm{H}_{162} \mathrm{O}_{34} \mathrm{~N}_{16} \mathrm{P}$ & 145 & 1.45 & 9.3 & 145 \\
\hline $18 \mathrm{Jul}$ & Lower & 14.7 & 42.9 & 28.6 & 13.7 & $\mathrm{C}_{92} \mathrm{H}_{149} \mathrm{O}_{30} \mathrm{~N}_{12} \mathrm{P}$ & 131 & 1.43 & 10.6 & 131 \\
\hline $22 \mathrm{Jul}$ & Lower & 15.8 & 41.7 & 22.6 & 19.9 & $\mathrm{C}_{82} \mathrm{H}_{133} \mathrm{O}_{31} \mathrm{~N}_{11} \mathrm{P}$ & 116 & 1.41 & 10.1 & 116 \\
\hline $26 \mathrm{Jul}$ & Lower & 14.2 & 44.9 & 26.9 & 14.0 & $\mathrm{C}_{95} \mathrm{H}_{153} \mathrm{O}_{31} \mathrm{~N}_{13} \mathrm{P}$ & 135 & 1.43 & 10.2 & 135 \\
\hline $17 \mathrm{Sep}$ & Lower & 14.3 & 42.4 & 25.0 & 18.3 & $\mathrm{C}_{92} \mathrm{H}_{150} \mathrm{O}_{33} \mathrm{~N}_{13} \mathrm{P}$ & 131 & 1.42 & 10.4 & 131 \\
\hline 19 Sep & Lower & 17.9 & 35.9 & 14.1 & 32.2 & $\mathrm{C}_{68} \mathrm{H}_{111} \mathrm{O}_{32} \mathrm{~N}_{9} \mathrm{P}$ & 93 & 1.37 & 10.0 & 93 \\
\hline 23 Sep & Lower & 8.5 & 48.6 & 10.6 & 32.3 & $\mathrm{C}_{145} \mathrm{H}_{233} \mathrm{O}_{65} \mathrm{~N}_{22} \mathrm{P}$ & 201 & 1.38 & 9.1 & 201 \\
\hline 26 Sep & Lower & 14.0 & 39.3 & 9.9 & 36.8 & $\mathrm{C}_{86} \mathrm{H}_{138} \mathrm{O}_{42} \mathrm{~N}_{12} \mathrm{P}$ & 116 & 1.35 & 9.6 & 116 \\
\hline
\end{tabular}

ranged from $60-65 \%$ in the upper to $57-64 \%$ in the lower layer. In general, July was characterized by an increase in lipids and a decrease in carbohydrates from surface to bottom. During the strong and weak summer upwelling, there was an increase of Pho, Prt and Lip at the expense of a decrease of PCho. The opposite was observed during the summer relaxation period. In general, July was characterized by a progressive increase of Lip with the weakness of upwelling due to preferential mineralization of Pho and Prt in shallower levels (Torres-López et al. 2005). In September, Pho+Prt ranged from 50 to $60 \%$, increasing from surface to bottom as a consequence of the combination of downwelling and fast sinking of fresh POM from the surface layer. In addition, this nutrient-limited period was characterized by a high proportion of PCho (Table 2).

The stoichiometric ratios of conversion of dissolved oxygen production into organic carbon $(\mathrm{Rc})$, nitrogen $(\mathrm{Rn})$ and phosphorus (Rp) for the upper and lower layers were obtained from the chemical formulas of POM (Table 2). These stoichiometric ratios were used to transform the biogeochemical rates obtained in different unities into a homogeneous currency (nitrogen).

\section{Metabolic balance of the microbial loop with phytoplankton}

Pg reached a surface maximum on 18 July (Fig. 2c, Table 3), during the strong summer upwelling, coinciding with the positive residual circulation pattern
(Fig. 2b) promoted by shelf northerly winds (Fig. 2a). This $P g$ maximum was accompanied by high chl $a$ and POC levels (our Fig. 2e; Fig. 2 in Piedracoba et al. this volume). The HPLC analysis of phytoplankton pigments revealed the predominance of species in the micro- and nanoplankton fraction $(>5 \mu \mathrm{m})$; picoplankton $(<5 \mu \mathrm{m})$ never accounted for $>5 \%$ of total chl $a$. The pigment composition in the micro- and nanoplankton fraction was characterized by high levels of fucoxanthin (ranging from 0.36 to $8.30 \mu \mathrm{g} \mathrm{I}^{-1}$, Fig. 2f). Neither acyloxy-fucoxanthin derivatives nor chl $C$-galactolipid esters were detected in more than trace amounts, but chl c3 (Fig. 2g) was relatively abundant during this period. This pigment signature suggests the importance of chl c3-containing diatom species. More than $4 \times 10^{6}$ cells $1^{-1}$ of Leptocylindrus danicus were counted on 18 July.

During the summer relaxation period, $P g$ decreased (268 $\mathrm{mmol} \mathrm{O}_{2} \mathrm{~m}^{-2} \mathrm{~d}^{-1}$ ) and a subsurface $R$ maximum (222 mmol $\mathrm{O}_{2} \mathrm{~m}^{-2} \mathrm{~d}^{-1}$ ) at $20 \mathrm{~m}$ depth was recorded (Fig. 2d). It coincided with a subsurface chl a and fucoxanthin maximum (Fig. 2e,f), suggesting that it corresponded to the same diatom population that caused the surface maximum of $P g$ during the previous strong summer upwelling. In any case, the water column integrated $R$ was lower than $P g$ and, therefore, the system was autotrophic. Significant amounts of chlorophyllide a (up to $1.33 \mu \mathrm{g} \mathrm{l}^{-1}$ in surface samples on 18 July) were found during this period. The distribution of chlorophyllide a (Fig. $2 \mathrm{~h}$ ) followed the same vertical distribution of chl $a$ and fucoxanthin, indicating that the presence of this degradation pigment can be 

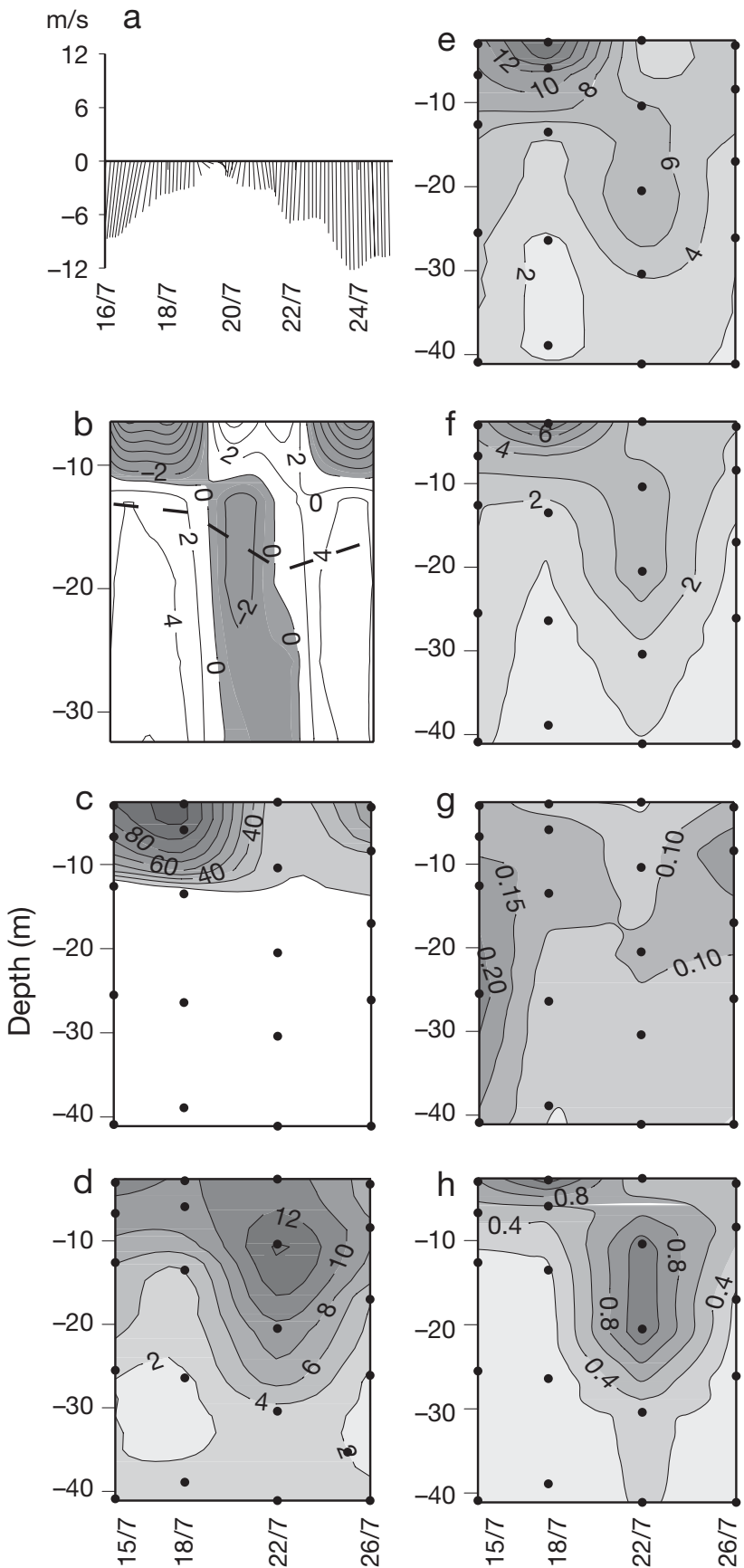

Fig. 2. July 2002. (a) Time course of shelf winds, in $\mathrm{m} \mathrm{s}^{-1}$; (b) residual currents, in $\mathrm{cm} \mathrm{s}^{-1}$; (c) gross primary production, in $\mu$ mol $\mathrm{O}_{2} \mathrm{~kg}^{-1} \mathrm{~d}^{-1}$; (d) respiration, in $\mu \mathrm{mol} \mathrm{O}_{2} \mathrm{~kg}^{-1} \mathrm{~d}^{-1}$;

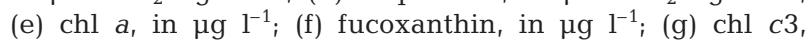
in $\mu \mathrm{g} \mathrm{l}^{-1}$; and (h) chlorophyllide $a$, in $\mu \mathrm{mol} \mathrm{l}^{-1}$

also linked to the same phytoplankton group. However, the vertical distribution of chl $c 3$ did not match the same vertical gradient exactly (Fig. 2g). The occurrence of small amounts of peridinin (ranging from 0.09 to $0.77 \mu \mathrm{g} \mathrm{l}^{-1}$ ) indicates the presence of type 1 dinoflagellates (sensu Jeffrey \& Wright 2006).
During the weak summer upwelling period, the positive residual circulation pattern promoted the entry of nutrient-rich waters (Fig. 2 in Piedracoba et al. 2008) that caused a remarkable $P g$ increase, although the level of nutrients was lower than during the strong summer upwelling period. Higher $R$ values reached shallower waters in relation to the previous period. $P g$ and $R$ maxima occurred at the same level.

The photic-zone-integrated f-ratio, $(P g-R) / P g$ (Quiñones \& Platt 1991), decreased from the strong ( $87 \%)$ to the weak summer upwelling ( $40 \%$ ). Therefore, the fraction of $P g$ available to be exported (horizontally and/or vertically) or to be transferred to higher trophic levels tended to decrease during the study period.

During the autumn downwelling (17 to 19 September), the system was balanced $(P g \sim R$, Fig. 3c,d, Table 3 ), coinciding with very low $\mathrm{Chl}$ and nutrient levels (our Fig. 3e; Fig. 4 in Piedracoba et al. 2008). The size distribution of pigments revealed a higher contribution of picoplankton, especially in subsurface samples: 16.1 and $29.7 \%$ of total chl $a$ at $25 \mathrm{~m}$ depth on 17 and 19 September, respectively (Fig. 3e). The picoplankton pigment composition of these samples was characterized by the occurrence of zeaxanthin and chl $b$, suggesting the presence of cyanobacteria. The contribution of picoplanktonic chl a to total chl a was $<6 \%$ in the remaining samples.

The pigment composition of micro- and nanoplankton was characterized by a high content of peridinin (up to $11.28 \mathrm{\mu g} \mathrm{l}^{-1}$, Fig. 3f), indicating the predominance of type 1 dinoflagellates (Jeffrey \& Wright 2006). Smaller amounts of fucoxanthin (ranging from 0.08 to $1.14 \mathrm{\mu g} \mathrm{l}^{-1}$ ) were found with no acyloxy-fucoxanthin derivatives, chl $c 3$ or nonpolar chl $c$ derivatives, indicating the occurrence of diatoms (Jeffrey \& Wright 2006). Alloxanthin, a marker pigment for cryptophytes, was also detected in small amounts (from 0.04 to $0.31 \mathrm{\mu g} \mathrm{l}^{-1}$, Fig. 3g). On 19 September, $0.6 \times 10^{6}$ cells l$^{-1}$ of Cryptophyceae sp. were counted.

Table 3. Depth average gross $(P g)$ primary production and respiration $(R)$ rates in $\mathrm{O}_{2}$ units $\left(\mathrm{mmol} \mathrm{m}^{-2} \mathrm{~d}^{-1}\right)$ for the upper and lower layer of the middle segment of the Ría de Vigo during the sampling dates

\begin{tabular}{|lcccc|}
\hline & \multicolumn{2}{c}{$p$} & \multicolumn{2}{c|}{$R$} \\
Date & Upper & Lower & Upper & Lower \\
\hline 15 Jul & 518 & 0 & 80 & 85 \\
18 Jul & 697 & 0 & 75 & 49 \\
22 Jul & 268 & 0 & 222 & 89 \\
26 Jul & 365 & 0 & 95 & 51 \\
17 Sep & 21 & 0 & 56 & 78 \\
19 Sep & 119 & 0 & 61 & 75 \\
23 Sep & 277 & 0 & 135 & 89 \\
26 Sep & 84 & 0 & 60 & 66 \\
\hline
\end{tabular}



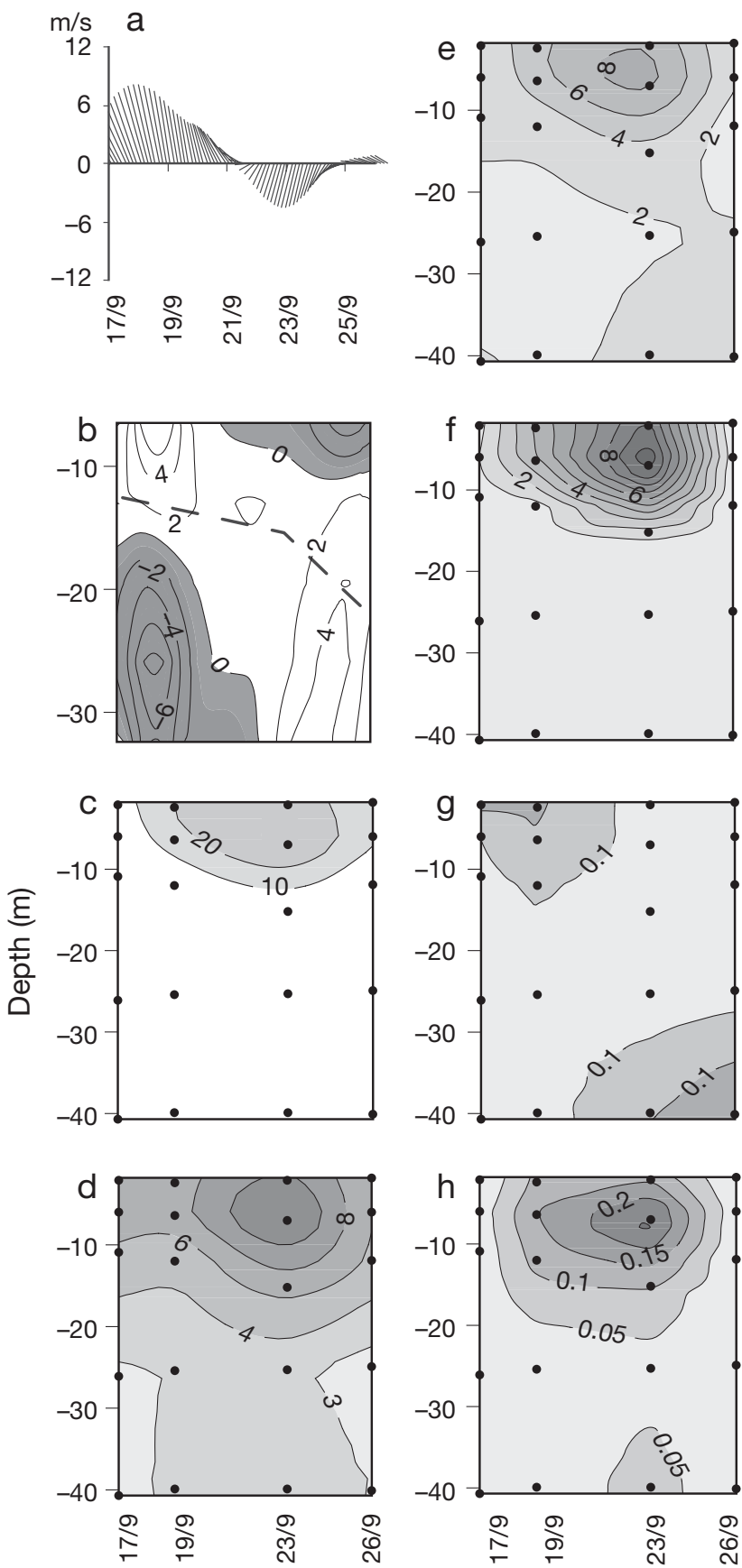

Fig. 3. September 2002. (a) Time course of shelf winds, in $\mathrm{m} \mathrm{s}^{-1}$; (b) residual currents, in $\mathrm{cm} \mathrm{s}^{-1}$; (c) gross primary production, in $\mu \mathrm{mol} \mathrm{O} \mathrm{kg}^{-1} \mathrm{~d}^{-1}$; (d) respiration, in $\mu \mathrm{mol} \mathrm{O} \mathrm{Kg}^{-1} \mathrm{~d}^{-1}$; (e) chl $a_{\text {, }}$

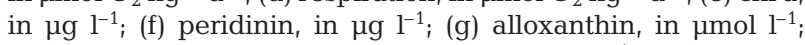
and (h) chlorophyllide $a$, in $\mu \mathrm{mol}^{-1}$

During the beginning of the transition period, Chl increased in the upper layer but $P g$ was low compared with $R$. The vertical distribution of peridinin was restricted to the photic zone (within the first $15 \mathrm{~m}$ of the water column), and reached a maximum at the $50 \%$ PAR on 19 September (Fig. 3f). Fucoxanthin, in much smaller amounts, was more widely distributed. As in July, chlorophyllide a was detected, but in much lower concentrations (up to $0.28 \mu \mathrm{g} \mathrm{l}^{-1}$ ). Chlorophyllide a reached a maximum at the $50 \%$ PAR on 23 September, but significant amounts were also detected at the bottom layer the same day (Fig. 3h).

When the hydrodynamic conditions changed to upwelling, a $P g$ maximum occurred $\left(277 \mathrm{mmol} \mathrm{O}_{2} \mathrm{~m}^{-2}\right.$ $\mathrm{d}^{-1}$ ), although it was nearly $1 / 3$ of the maximum in July. By contrast, $R$ was similar in both periods. On 26 September, $10^{6}$ cells $\mathrm{l}^{-1}$ of Skeletonema costatum, Chaetoceros spp. and Thalassiosira nana were found. The contribution of picoplankton to total chl a was $14.1 \%$ at the surface on 26 September. Alloxanthin appeared near the surface on 17 and 19 September, but the situation reversed later in the month, with the highest values detected at the lowest depths sampled on 23 and 26 September (Fig. 3g), indicating that cryptophytes were the main contributors to the chl a measured there (Fig. 3e).

The photic-zone-integrated f-ratio ranged from $-59 \%$ during the autumn downwelling to $40 \%$ during the weak autumn upwelling. The negative sign shows that the system was heterotrophic $(R>P)$.

\section{Microzooplankton grazing}

The 4 dilution experiments produced contrasting results: $\mu=1.32 \pm 0.24 \mathrm{~d}^{-1}$ (average \pm standard error) and $g=1.04 \pm 0.30 \mathrm{~d}^{-1}$ on 18 July. Similar values were obtained on 26 July: $\mu=1.43 \pm 0.10 \mathrm{~d}^{-1}$ and $\mathrm{g}=0.85 \pm$ $0.20 \mathrm{~d}^{-1}$. By contrast, $\mu$ and $g$ were considerably lower in September: $\mu=0.36 \pm 0.02 \mathrm{~d}^{-1}$ and $g=0.31 \pm 0.10 \mathrm{~d}^{-1}$ on 19 September and $\mu=0.32 \pm 0.2 \mathrm{~d}^{-1}$ and $g=0.13 \pm$ $0.20 \mathrm{~d}^{-1}$ on 26 September.

We assumed a constant $g$ with depth on the basis that microheterotrophs and phytoplankton species composition do not change significantly through the photic layer (Nogueira et al. 2000). The photic-layeraveraged growth rate, $\langle\mu\rangle$, was calculated from the $\mu$ of the $50 \%$ PAR and the proportion between the $50 \%$ PAR $\left(P_{50 \%}, \mathrm{mmol} \mathrm{O}_{2} \mathrm{~m}^{-3} \mathrm{~d}^{-1}\right)$ and the photic layer integrated $\mathrm{O}_{2}$ primary production $\left(\langle P g\rangle, \mathrm{mmol} \mathrm{O}_{2} \mathrm{~m}^{-2}\right.$ $\left.\mathrm{d}^{-1}\right)$ :

$$
<\mu>=\frac{<P g>}{P g_{50 \%} \cdot z} \cdot \mu
$$

where $z$ (in $\mathrm{m}$ ) is the $1 \%$ PAR depth. The resultant $<\mu>$ were $0.82 \pm 0.06 \mathrm{~d}^{-1}$ on 18 July, $0.65 \pm 0.03 \mathrm{~d}^{-1}$ on 26 July, $0.20 \pm 0.01 \mathrm{~d}^{-1}$ on 19 September and $0.24 \pm$ $0.08 \mathrm{~d}^{-1}$ on 26 September.

Further assumptions are needed to calculate $<\mu>$ and $g$ for the dates when grazing experiments were not carried out. The $g / \mu$ ratio at the $50 \%$ PAR measured on 
18 July was applied to 15 and 22 July. In September, the $g / \mu$ ratio measured on 19 and 26 September was applied to 17 and 23 September, respectively. These assignments were based on the similarity of the hydrographic and dynamic conditions among sampling dates. Once the $g / \mu$ ratios were set, $\mu$ for 15 and 22 July and 17 and 23 September were calculated using Calbet \& Landry's (2004) formula by finding the value of $\mu$ that produces the measured $P_{50 \%}$ :

$$
P g_{50 \%}=\left(\frac{\Delta \mathrm{O}_{2}}{\Delta \mathrm{Chl}}\right) \cdot \mu \cdot \mathrm{Chl}_{0} \cdot \frac{\mathrm{e}^{\mu-g}-1}{\mu-g}
$$

where $\mathrm{Chl}_{0}$ is the initial chl a concentration and $\left(\frac{\Delta \mathrm{O}_{2}}{\Delta \mathrm{Chl}}\right)$ is the stoichiometric ratio of conversion of chl a into $\mathrm{O}_{2}$ changes, obtained from the average composition of POM in the photic layer each sampling date (Table 2). To test the confidence of Eq. (9) for the calculation of $\mu$ and $g$, it was solved for the dates when grazing experiments were conducted; the difference between the measured and calculated $P g_{50} \%$ was less than $\pm 20 \%$.

The values of $\mu$ and $g$ obtained were $1.89 \pm 0.19$ and $1.58 \pm 0.39 \mathrm{~d}^{-1}$ on 15 July; $0.40 \pm 0.04$ and $0.31 \pm 0.08$ $\mathrm{d}^{-1}$ on 22 July; $0.17 \pm 0.02$ and $0.14 \pm 0.02 \mathrm{~d}^{-1}$ on 17 September; and $0.41 \pm 0.04$ and $0.16 \pm 0.06 \mathrm{~d}^{-1}$ on 23 September. Using Eq. (8), $<\mu>$ was $1.13 \pm 0.07$ on 15 July, $0.31 \pm 0.03$ on 22 July, $0.09 \pm 0.03$ on 17 September and $0.30 \pm 0.02 \mathrm{~d}^{-1}$ on 23 September. Finally, the photic layer integrated grazing rate (in $\mathrm{g} \mathrm{N} \mathrm{m}^{-2}$ $\left.\mathrm{d}^{-1}\right), G$, was calculated as:

$$
G=\frac{g}{<\mu>} \cdot\langle P g>\cdot z \cdot \mathrm{Rn}
$$

Table 4 summarizes the direct and indirect estimates of microzooplankton grazing parameters. The percentage of $P g$ taken up by microheterotrophs ranged from 64 to $81 \%$ during July and, decreased from 115 to $44 \%$ during September.

\section{Vertical fluxes of biogenic organic materials}

Sedimentation rates were $0.34 \pm 0.03$ and $0.14 \pm$ $0.04 \mathrm{~g} \mathrm{~N} \mathrm{~m}^{-2} \mathrm{~d}^{-1}$ on 18 and 22 July and $0.15 \pm 0.03$ and $0.17 \pm 0.04 \mathrm{~g} \mathrm{~N} \mathrm{~m}^{-2} \mathrm{~d}^{-1}$ on 19 and 26 September. Dividing the sedimentation rates by the average PON concentration of the photic layer, sedimentation velocities $(\omega)$ of $5.7 \pm 0.7,2.6 \pm 0.9,2.4 \pm 0.5$ and $3.6 \pm 0.9 \mathrm{~m} \mathrm{~d}^{-1}$ were calculated. Considering the depth where the trap was deployed (the $1 \%$ PAR), sedimentation times of $2 \mathrm{~d}$ on 18 July, $8 \mathrm{~d}$ on 22 July, $8 \mathrm{~d}$ on 19 September and $5 \mathrm{~d}$ on 26 September were computed. Since the sampling frequency was in general lower than the sedimentation time, time-average sedimentation velocities $\omega$ of $5.8 \pm 0.7$ and $2.4 \pm 0.8 \mathrm{~m} \mathrm{~d}^{-1}$ were estimated for 15-18 and 18-22 July, and $2.7 \pm 0.6,2.3 \pm 0.7$ and $2.6 \pm 0.7 \mathrm{~m} \mathrm{~d}^{-1}$ for $17-19,19-23$, and 23-26 September, which takes into consideration the days that sediment traps were not deployed. Vertical convective and diffusive PON and DON' fluxes were also calculated in each period (Table 5). DON' was obtained by subtracting the average DON in oceanic ENACW (3.6 \pm $0.4 \mathrm{mmol} \mathrm{l}^{-1}$; Nieto-Cid et al. 2005) to the measured DON concentration.

In July, a decrease of the downward vertical flux of organic nitrogen (DON' + PON) was observed in parallel to the weakening of upwelling, mainly due to a net reduction of turbulent mixing (Table 5) and sedimentation. Sedimentation was the dominant vertical transport process: it was responsible for 70 to $90 \%$ of the vertical flux. PON was the prevalent form transported by vertical convection ( $80 \%$ ), while the percentage of $\mathrm{DON}^{\prime}$ and PON transported by turbulent mixing was 50:50, except during the strong summer upwelling, when it changed to 30:70 (DON':PON).

In September, all the material previously accumulated in the photic layer was transported downwards during the autumn downwelling, with vertical convec-

Table 4. Summary of the grazing incubation experiments. $<\mathrm{Chl}_{0}>$ is the initial chl $a$ in the photic layer (in $\mu g \mathrm{l}^{-1}$ ); $\mathrm{Chl}_{0}$ is the initial chl $a$ in the $50 \%$ PAR (in $\mu \mathrm{g} \mathrm{l}^{-1}$ ); $\mathrm{z}_{\mathrm{m}}$ is the depth of the $1 \%$ PAR (in $\mathrm{m}$ ); $\mu$ is the phytoplankton growth rate in the $50 \%$ PAR $\left(\mathrm{in} \mathrm{d}^{-1}\right) ; \mathrm{g}$ is the microzooplankton grazing rate in the $50 \%$ PAR (in $\left.\mathrm{d}^{-1}\right)_{;}<\mu>$ is the average $\mu$ in the photic layer; $\mathrm{PP}_{50} \%$ is the $\mathrm{O}_{2}$ primary production rate in the $50 \%$ PAR (in mmol $\left.\mathrm{O}_{2} \mathrm{~m}^{-3} \mathrm{~d}^{-1}\right) ;\left(\frac{\Delta \mathrm{C}}{\Delta \mathrm{Chl}}\right)$ is the stoichiometric ratio of conversion of Chl $a$ into $\mathrm{C}$ changes obtained from the average composition of POM in the upper layer each sampling date (Table 2)

\begin{tabular}{|lcrrrrrrrr|}
\hline Date & $<\mathrm{Chl}_{0}>$ & $z_{\mathrm{m}}$ & $\mathrm{Chl}_{0}$ & $\mu$ & $g$ & $P g_{50 \%}$ & $<\mu>$ & $\left(\frac{\Delta \mathrm{C}}{\Delta \mathrm{Chl}}\right)$ & $g^{*}<\mathrm{Chl} a>/<P g>$ \\
\hline 15 Jul & 8.88 & 12.6 & 10.65 & 1.89 & 1.58 & 23.45 & 1.13 & 2.67 & $80 \%$ \\
18 Jul & 9.82 & 13.5 & 18.92 & 1.32 & 1.04 & 24.88 & 0.82 & 2.9 & $51 \%$ \\
22 Jul & 6.14 & 20.5 & 3.06 & 0.40 & 0.31 & 1.26 & 0.31 & 11.14 & $140 \%$ \\
26 Jul & 4.24 & 17.0 & 5.56 & 1.43 & 0.85 & 9.22 & 0.65 & 4.46 & $67 \%$ \\
17 Sep & 2.30 & 10.9 & 2.22 & 0.17 & 0.14 & 0.37 & 0.09 & 8.61 & $164 \%$ \\
19 Sep & 4.40 & 12.0 & 5.71 & 0.36 & 0.31 & 2.40 & 0.20 & 6.76 & $108 \%$ \\
23 Sep & 6.80 & 15.2 & 8.06 & 0.41 & 0.17 & 3.73 & 0.30 & 5.66 & $44 \%$ \\
26 Sep & 1.79 & 11.9 & 2.00 & 0.32 & 0.13 & 0.67 & 0.25 & 11.53 & $45 \%$ \\
\hline
\end{tabular}


Table 5. Vertical convective and diffusive mixing PON and $\mathrm{DON}^{\prime}$ fluxes $\left(<0\right.$, upward; $>0$, downward) in $\mathrm{mg} \mathrm{N} \mathrm{m}^{-2} \mathrm{~d}^{-1}$

\begin{tabular}{|lrrrcc|}
\hline Period & Interval & $\mathrm{DON}^{\prime} \cdot V_{\mathrm{Z}}$ & $\mathrm{DON}^{\prime} \cdot K_{\mathrm{Z}} / \Delta z$ & $\mathrm{PON} \cdot V_{\mathrm{Z}}$ & $\mathrm{PON} \cdot K_{\mathrm{Z}} / \Delta z$ \\
\hline $\begin{array}{l}\text { Strong summer } \\
\text { upwelling }\end{array}$ & 15-18 Jul & $-17 \pm 4$ & $141 \pm 3$ & $-75 \pm 13$ & $121 \pm 6$ \\
$\begin{array}{c}\text { Summer } \\
\text { relaxation }\end{array}$ & 18-22 Jul & $3 \pm 0$ & $17 \pm 0$ & $21 \pm 5$ & $14 \pm 1$ \\
$\begin{array}{c}\text { Weak summer } \\
\text { upwelling }\end{array}$ & 22-26 Jul & $-19 \pm 6$ & $13 \pm 1$ & $-71 \pm 18$ & $30 \pm 3$ \\
$\begin{array}{c}\text { Autumn } \\
\text { downwelling }\end{array}$ & 17-19 Sep & $101 \pm 2$ & $71 \pm 3$ & $142 \pm 3$ & $132 \pm 3$ \\
$\begin{array}{c}\text { Autumn } \\
\text { transition }\end{array}$ & 19-23 Sep & $19 \pm 3$ & $136 \pm 3$ & $40 \pm 6$ & $-1 \pm 4$ \\
$\begin{array}{c}\text { Autumn } \\
\text { upwelling }\end{array}$ & 23-26 Sep & $-68 \pm 6$ & $71 \pm 2$ & $-88 \pm 10$ & $-138 \pm 2$ \\
\hline
\end{tabular}

tion dominating over turbulent mixing. During the transition from autumn downwelling to upwelling, turbulent mixing of DON' was the dominant vertical flux. Sedimentation rates increased with the re-establishment of upwelling $(70 \%$ of the PON was transported by sedimentation and $30 \%$ by turbulent mixing).

\section{DISCUSSION AND CONCLUSIONS}

\section{In vitro approach}

Pelagic community production and respiration rates were measured concomitantly with microzooplankton grazing and sedimentation rates for the first time in the coastal upwelling system of the Ría de Vigo. The resulting carbon and nitrogen fluxes for the different hydrographic situations are summarized in Figs. 4 \& 5 .

In July, $P g$ decreased from $0.94 \pm$ $0.04 \mathrm{~g} \mathrm{~N} \mathrm{~m}^{-2} \mathrm{~d}^{-1}$ during the spin-down of strong summer upwelling, when phytoplankton grows at the expense of the previously upwelled nutrients, to $0.47 \pm 0.03 \mathrm{~g} \mathrm{~N} \mathrm{~m}^{-2} \mathrm{~d}^{-1}$ during the weak summer upwelling, because of the progressive reduction of the entry of nutrient salts. In contrast, $R$ increased from 13 to $49 \%$ of $P g$ in the photic layer. Consequently, the net microbial community
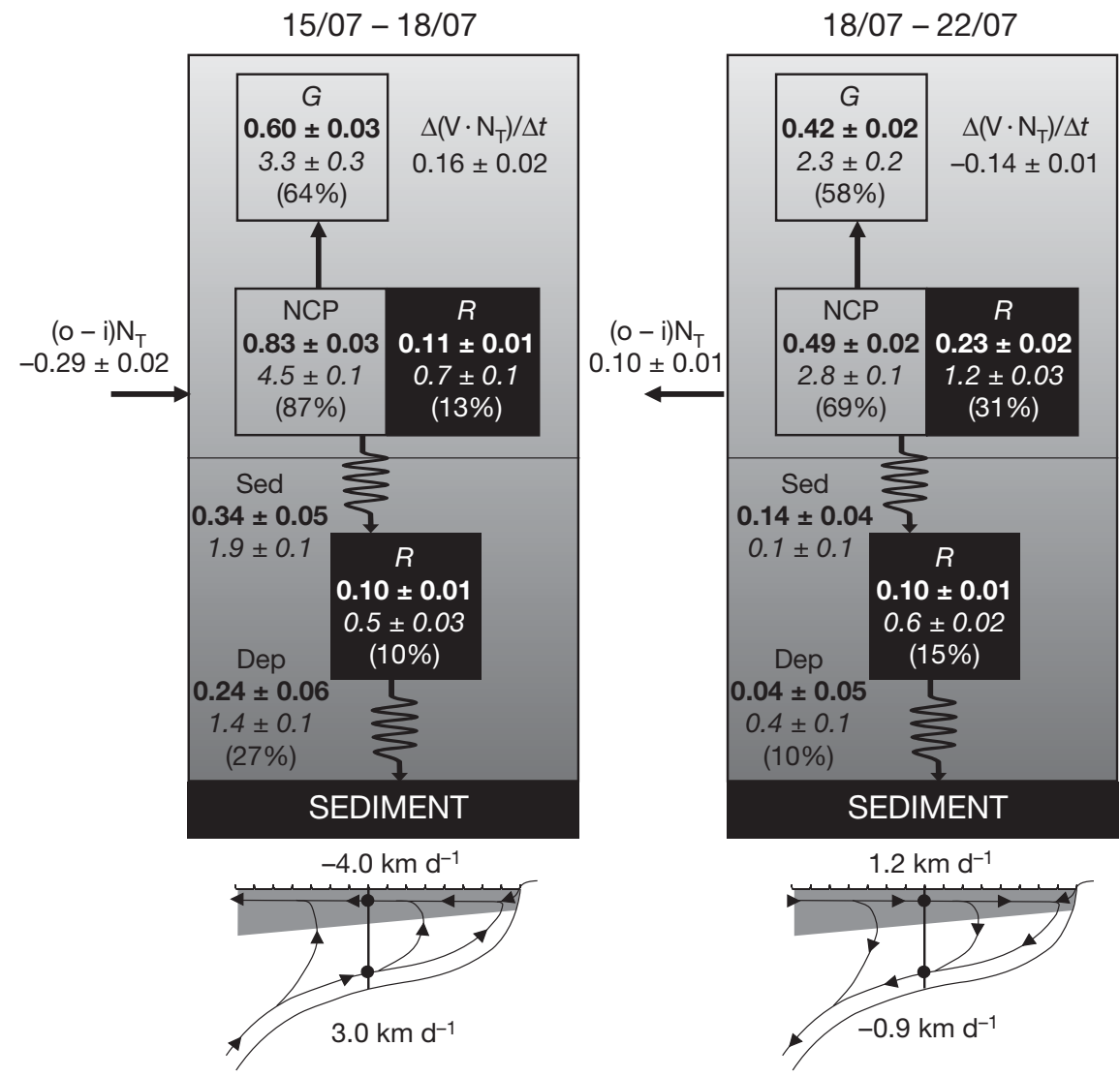

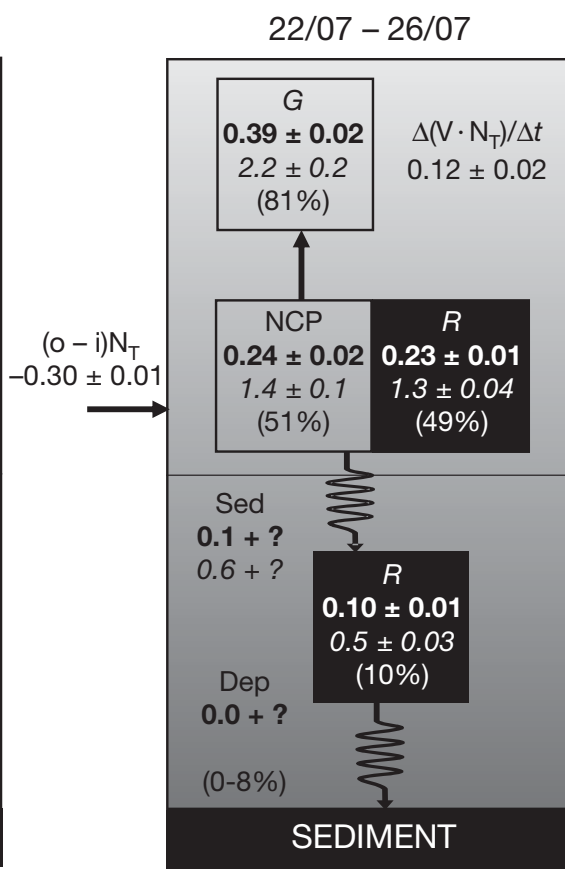

$-3.6 \mathrm{~km} \mathrm{~d}^{-1}$

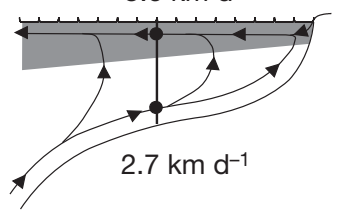

Fig. 4. Upper panels: Nitrogen (in bold) and carbon (in italics) fluxes in $\mathrm{g} \mathrm{m}^{-2} \mathrm{~d}^{-1}$, from in vitro measurements during July 2002. NCP, net community production; $R$, community respiration; $G$, microzooplankton grazing; Sed, sedimentation; Dep, deposition; $\%$, fluxes referred to $P g$, the gross primary production $;(\mathrm{o}-\mathrm{i})_{\mathrm{T}}$, outputs minus inputs of $\mathrm{N}_{\mathrm{T}} ; \Delta\left(\mathrm{V} \cdot \mathrm{N}_{\mathrm{T}}\right) / \Delta t$, accumulation of $\mathrm{N}_{\mathrm{T}}$ (from Piedracoba et al. 2008). Lower panels: average surface and bottom residual currents $\left(\mathrm{km} \mathrm{d}^{-1}\right)$ 


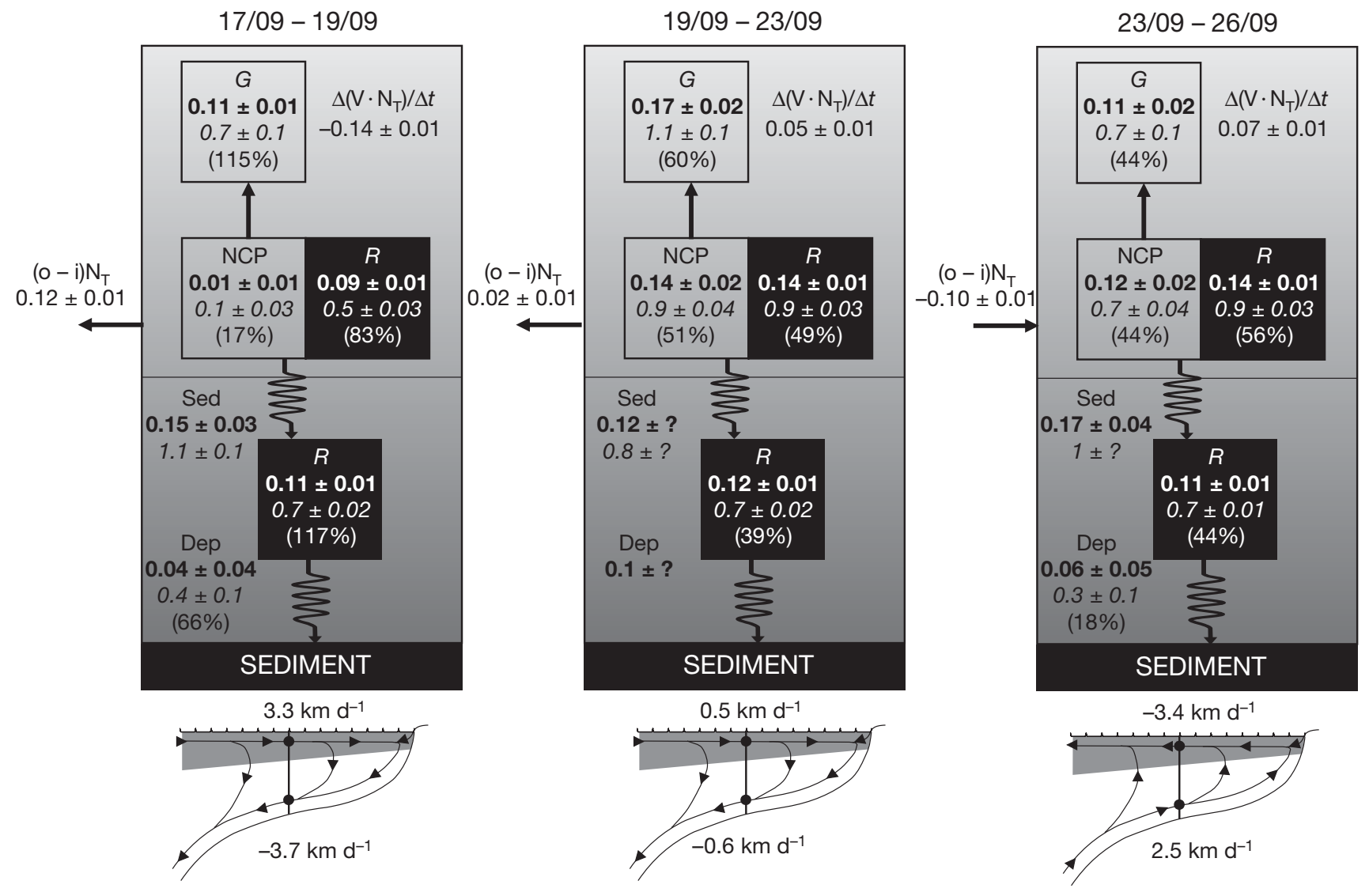

Fig. 5. Upper panels: Nitrogen (in bold) and carbon (in italics) fluxes in $\mathrm{g} \mathrm{m}^{-2} \mathrm{~d}^{-1}$, from in vitro measurements during September 2002. NCP, net community production; $R$, community respiration; $G$, microzooplankton grazing; Sed, sedimentation; Dep, deposition; \%, fluxes referred to $P g$, the gross primary production; $(\mathrm{o}-\mathrm{i})_{\mathrm{T}}$, outputs minus inputs of $\mathrm{N}_{\mathrm{T}} ; \Delta\left(\mathrm{V} \cdot \mathrm{N}_{\mathrm{T}}\right) / \Delta t$, accumulation of $\mathrm{N}_{\mathrm{T}}$ (from Piedracoba et al. 2008). Lower panels: average surface and bottom residual currents $\left(\mathrm{km}^{-1}\right.$ )

production, $\mathrm{NCP}(=P g-R)$ reduced in parallel with the decrease of $P g$, from $0.83 \pm 0.03$ during the strong summer upwelling to $0.24 \pm 0.02 \mathrm{~g} \mathrm{~N} \mathrm{~m}^{-2} \mathrm{~d}^{-1}$ during the weak summer upwelling. The resulting average $P g$ in July was $0.71 \mathrm{~g} \mathrm{~N} \mathrm{~m}^{-2} \mathrm{~d}^{-1}, 27 \%$ being respired in the photic zone and $14 \%$ in the aphotic zone. Therefore the average NCP was $0.42 \pm 0.03 \mathrm{~g} \mathrm{~N} \mathrm{~m}^{-2}$ $\mathrm{d}^{-1}$ and the resulting f-ratio was 0.66 . This value is comparable to the f-ratio obtained by Moncoiffé et al. (2000) at the same site from April to November 1991, and also with the value of 0.63 obtained in the nearby Ría de Arousa by Álvarez-Salgado et al. (1996). The f-ratio decreased from 0.87 for the strong summer upwelling to 0.53 for the summer relaxation and 0.40 for weak summer upwelling. Microzooplankton grazing ranged from $0.60 \pm 0.03 \mathrm{~g} \mathrm{~N} \mathrm{~m}^{-2} \mathrm{~d}^{-1}(64 \pm 8 \%$ of $P g$ ) during the strong summer upwelling to $0.39 \pm$ $0.02 \mathrm{~g} \mathrm{~N} \mathrm{~m}^{-2} \mathrm{~d}^{-1}(83 \pm 9 \%$ of $P g)$ during the weak summer upwelling. These grazing rates imply that, despite the high $P g$, the direct transference of phytoplankton biomass to higher trophic levels was reduced. Sedimentation also decreased in parallel to the reduction of $P g$, from $0.34 \pm 0.05$ during the strong summer upwelling to $0.14 \pm 0.04 \mathrm{~g} \mathrm{~N} \mathrm{~m}^{-2} \mathrm{~d}^{-1}$ during the subsequent relaxation. Sedimentation during the weak summer upwelling had to be at least 0.1 $\mathrm{g} \mathrm{N} \mathrm{m}^{-2} \mathrm{~d}^{-1}$ to balance the respiration of the aphotic layer. It is clear that phytoplankton production was not able to support the respiration, microzooplankton grazing and sedimentation rates measured during July, suggesting that (1) sedimentation of microzooplankton occured; and/or (2) the sediment traps were collecting a material transported either from the inner ría or from the shelf (note that the sinking time was between 2 and $8 \mathrm{~d}$ ). The aphotic layer respiration was nearly constant in July $\left(0.1 \pm 0.01 \mathrm{~g} \mathrm{~N} \mathrm{~m}^{-2} \mathrm{~d}^{-1}\right)$ but it increased from $10 \%$ of $\mathrm{Pg}$ during the strong summer upwelling to $22 \%$ of $\mathrm{Pg}$ during the weak summer upwelling. The balance of sedimentation minus aphotic layer respiration, Dep $(=\operatorname{Sed}-R)$, represents the biogenic material deposited over the pelagic sediments of the ría. Dep decreased with $P g$ and sedimentation, and also with the increase of $\% R / P g$ in the aphotic layer. 
In September, $P g$ increased from $0.10 \pm 0.02$ during the initial downwelling to $0.28 \pm 0.03 \mathrm{~g} \mathrm{~N} \mathrm{~m}^{-2} \mathrm{~d}^{-1}$ during the final upwelling period. $R$ in the photic layer also decreased from 83 to $56 \%$ of $P g$. Consequently, the photic layer NCP was extremely low, ranging from $0.01 \pm 0.01$ to $0.14 \pm 0.02 \mathrm{~g} \mathrm{~N} \mathrm{~m}^{-2} \mathrm{~d}^{-1}$. The low productivity was the reason behind the low microzooplankton grazing rates compared with July. Microzooplankton grazed from $115 \pm 32 \%$ to $44 \pm 12 \%$ of $P g$ throughout the study period, suggesting that phytoplankton either previously accumulated in the study site or advected from the inner ría or the shelf are necessary to support microzooplankton grazing rates. Despite the low productivity, sedimentation rates in September were comparable to July. Again, sinking times between 5 and $8 \mathrm{~d}$ suggest that the sediment trap was not collecting the biogenic material produced during the collection time but the previously accumulated or transported either from the inner ría or the shelf. The aphotic layer $R$ was nearly constant during September at $0.11 \pm$ $0.01 \mathrm{~g} \mathrm{~N} \mathrm{~m}^{-2} \mathrm{~d}^{-1}\left(0.7 \pm 0.1 \mathrm{~g} \mathrm{C} \mathrm{m}^{-2} \mathrm{~d}^{-1}\right)$. Sedimentation during the autumn transition should be at least $0.12 \mathrm{~g}$ $\mathrm{N} \mathrm{m}^{-2} \mathrm{~d}^{-1}\left(0.8 \mathrm{~g} \mathrm{C} \mathrm{m}^{-2} \mathrm{~d}^{-1}\right)$ to balance the respiration of the aphotic layer. Dep fluxes were small in comparison with July.

Considering all sampling dates together, the average $P g$ coincided with the seasonal mean of $2.5 \pm 2.8 \mathrm{~g} \mathrm{C}$ $\mathrm{m}^{-2} \mathrm{~d}^{-1}$ estimated for the rías during the upwelling season (Fraga 1976, Bode \& Varela 1998, Tilstone et al. 1999, Moncoiffé et al. 2000, Teira et al. 2003, Varela et al. 2004, 2005). The average $R$ in the photic and aphotic layer was also comparable with the seasonal mean estimates of $43 \%$ and $25 \%$ of $P g$ respectively, obtained by Moncoiffé et al. (2000) at the same site during the upwelling season of 1991.

The microzooplankton grazing rates measured in the Ría de Vigo were generally within the range 60 to $75 \%$ of $\mathrm{Pg}$ reported in the literature (Calbet \& Landry 2004) and comparable to the values reported by Fileman \& Burkill (2001) in the NW Iberian shelf during an upwelling/relaxation event. High microzooplankton grazing rates contribute to keep most of the phytoplankton production within the microbial loop constituted by the microheterotrophs (bacteria and protozoa) and the autotrophic pro- and eukaryotic unicellular organisms (Sherr \& Sherr 1998). Trophic interactions within the microbial loop implied a lower efficiency in the transference of organic matter to the metazoan food web.

The few studies of sedimentation rates in this region were carried out in the Ría de Ferrol (Varela et al. 2003), the Ría de Pontevedra (Varela et al. 2004) and the western Iberian shelf and slope (Bode et al. 1998, Olli et al. 2001). Varela et al. $(2003,2004)$ obtained sedimentation rates ranging from 1.9 to $2.7 \mathrm{~g} \mathrm{C} \mathrm{m}^{-2} \mathrm{~d}^{-1}$ and from 0.5 to $1.8 \mathrm{~g} \mathrm{C} \mathrm{m}^{-2} \mathrm{~d}^{-1}$, respectively, and for similar seasonal periods, i.e. the same order as in the Ría de Vigo. The sedimentation fluxes measured in the Ría de Pontevedra were quantitatively related to the hydrography: a negative relationship was obtained between sedimentation and horizontal advection. The limited number of case studies prevented us from checking any quantitative relationship between the sedimentation and hydrography of the Ría de Vigo, and so only a qualitative approach can be made. In July, the nutrient entry during strong summer upwelling allowed phytoplankton growth. The subsequent relaxation caused phytoplankton at the surface on 18 July to sink to a subsurface maximum of chl $a$, fucoxanthin and chl $c 3$ on 22 July. However, during the weak summer upwelling, hydrodynamic conditions favored phytoplankton in the photic layer to flow out of the ría with the outgoing surface current. In September, despite the low productivity, sedimentation rates were similar to July. The low nutrient levels of the photic layer and the dominant downwelling conditions during the study period are likely the reasons behind this high sedimentation. Aggregates of phytoplankton cells usually occur when nutrients are depleted, producing high sinking rates (Riebesell 1989, Álvarez-Salgado 2005). Rapid sedimentation rates have been reported in the literature in relation to nutrient depletion in the photic layer by Smayda (1970), Waite et al. (1992) and Richardson \& Cullen (1995). Pigment distributions indicate that a dinoflagellate bloom developed during the autumn downwelling, which sank to the $25 \%$ PAR during the autumn relaxation. The subsurface maximum was dispersed by the surface outgoing current developed during the subsequent weak autumn upwelling. By contrast, Cryptophyceae sp., marked by the surface alloxantin maximum during the autumn downwelling, sank to the bottom during the autumn relaxation and was reintroduced in the ría by the bottom flow during the autumn upwelling. The ability of dinoflagellates for vertical migration (Figueiras et al. 1994, Fermín et al. 1996) could keep them at mid-water depths during the autumn relaxation, unlike cryptophytes, that sank to the bottom.

Olli et al. (2001) studied the vertical flux and composition of settling biogenic matter during a lagrangian experiment off the NW Spanish continental margin. They obtained POC fluxes of 90 to $240 \mathrm{mg} \mathrm{C} \mathrm{m}^{-2} \mathrm{~d}^{-1}$ over the shelf and 50 to $180 \mathrm{mg} \mathrm{C} \mathrm{m}^{-2} \mathrm{~d}^{-1}$ in the adjacent ocean. Although the magnitude of these sedimentation rates was lower than the fluxes obtained in the ría, they represented 14 to $26 \%$ of the integrated primary production per day on the shelf and 25 to $42 \%$ on the slope, i.e. similar percentages as during the upwelling/relaxation cycle of July 2002 in the Ría de Vigo. 


\section{Comparison of in vitro and in situ approaches}

The comparison between microbial and geochemical approaches to the metabolic balance for the 6 periods analyzed in this study is shown in Table 6 .

During the strong summer upwelling (15 to 18 July), the in vitro NCP was $0.73 \pm 0.04 \mathrm{~g} \mathrm{~N} \mathrm{~m}^{-2} \mathrm{~d}^{-1}$. If microzooplankton grazing $(G)$ is subtracted from $\mathrm{NCP}$, a surplus of $0.13 \pm 0.07 \mathrm{~g} \mathrm{~N} \mathrm{~m}^{-2} \mathrm{~d}^{-1}$ is obtained that is comparable with the in situ net ecosystem production $\left(\mathrm{NEP}_{\mathrm{T}}\right)$ obtained by Piedracoba et al. (2008). Note that the in situ $\mathrm{NEP}_{\mathrm{T}}$, as calculated from $\mathrm{N}$-nutrient changes, is $<0$ when nutrients are consumed (= organic matter production) and $>0$ when nutrients are produced (= organic matter respiration). Therefore, when $\mathrm{NCP}>0$ and $\mathrm{NEP}_{\mathrm{T}}<0$ the system showed an autotrophic status, and when $\mathrm{NCP}<0$ and $\mathrm{NEP}_{\mathrm{T}}>0$ it showed a heterotrophic status.

The in vitro NCP during the summer relaxation (18 to 22 July) was $0.39 \mathrm{~g} \mathrm{~N} \mathrm{~m}^{-2} \mathrm{~d}^{-1}$, and subtracting $G$, the system would be balanced. Accordingly, the in situ $\mathrm{NEP}_{\mathrm{T}}$ was also balanced.

In vitro $\mathrm{NCP}$ during the summer weak upwelling (22 to 26 July) was $0.14 \mathrm{~g} \mathrm{~N} \mathrm{~m}^{-2} \mathrm{~d}^{-1}$. In this case, $P g$ was not enough to support microzooplankton grazing. By contrast, the in situ $\mathrm{NEP}_{\mathrm{T}}$ was equivalent to the in vitro NCP but differed completely when $G$ is subtracted.

During the autumn downwelling period (17 to 19 September), the system was heterotrophic (NCP < 0 ). If $G$ is subtracted, the deficit was higher. In contrast, the in situ $\mathrm{NEP}_{\mathrm{T}}$ was $-0.02 \pm 0.01 \mathrm{~g} \mathrm{~N} \mathrm{~m}^{-2} \mathrm{~d}^{-1}$, suggesting that the study system was nearly balanced.

During the autumn relaxation period (19 to $23 \mathrm{Sep}$ tember), in vitro $\mathrm{NCP}$ was $0.02 \pm 0.03 \mathrm{~g} \mathrm{~N} \mathrm{~m}^{-2} \mathrm{~d}^{-1}$. Considering $G$, NCP was not enough to support the microheterotrophic community. The in situ $\mathrm{NEP}_{\mathrm{T}}$ was comparable with the in vitro approach.

In vitro measurements during the weak autumn upwelling showed an NCP of $0.01 \pm 0.03 \mathrm{~g} \mathrm{~N} \mathrm{~m}^{-2} \mathrm{~d}^{-1}$, i.e. a nearly balanced system unable to support the microzooplankton activity. The in situ $\mathrm{NEP}_{\mathrm{T}}$ also showed that the system was balanced.
The geochemical and microbial approaches were in agreement in 3 of the 6 periods analyzed in this study, specifically during the spin-down of strong summer upwelling, the summer relaxation, and the autumn transition period. The discrepancies intensified due to the high grazing fluxes, which revealed that the immediate fate of NCP was the microbial loop rather than being transferred to the metazoans. The imbalance between NCP and $G$ suggests that the system needed to import allochthonous organic matter to support the microheterotrophs. In July, the hydrodynamics (positive residual circulation) indicated that the organic matter was basically imported from the inner ría. In contrast, the dominant hydrodynamics in September (negative residual circulation) meant that the source of organic matter to support the metabolic requirements arrived from the shelf.

Several factors contribute to the differences between the geochemical and in situ balances. The in situ balance is representative for a station (5 depths), while the geochemical balance considers a volume of the ría. In addition, the incubations preformed to analyze the metabolic state of the system are affected by the "bottle effects'. During the incubation time $(24 \mathrm{~h})$ the initial conditions are modified and artefacts associated with isolating a portion of the community in containers can appear: reduced turbulence, unnatural light field and altered grazer communities. In addition, environmental changes during the incubation time cannot be reflected with an in vitro method, a relevant issue in a transient marine ecosystem such as the Ría de Vigo. Furthermore, incubations may give precise measurements for each component, but with method-dependent biases. If such biases occur, then the summed measurement will not accurately represent the net metabolism (Smith \& Hollibaugh 1993). On the other hand, the processes that occur in incubation bottles filled at a single site do not catch the different environments enclosed by the middle section of the ría (e.g. the culture of mussels on hanging ropes or the sedimentary basin of San Simon Bay). Finally, the high microzooplankton grazing did not correlate with respi-

Table 6. Comparison between in vitro and in situ approaches to the metabolic balance of the Ría de Vigo. $\mathrm{NCP}_{1} G$ and $\mathrm{NEP}_{\mathrm{T}}$ are in $\mathrm{mg} \mathrm{N} \mathrm{m} \mathrm{N}^{-2} \mathrm{~d}^{-1}$. Note that the system showed an autotrophic status when $\mathrm{NCP}>0$ and $\mathrm{NEP}_{\mathrm{T}}<0$, and a heterotrophic status when $\mathrm{NCP}<0$ and $\mathrm{NEP}_{\mathrm{T}}>0$. The periods in which both approaches are equivalent are shown in bold

\begin{tabular}{|llrr|}
\hline Period & Interval & NCP $-G$ & NEP \\
\hline Strong summer upwelling & $\mathbf{1 5 - 1 8 ~ J u l ~}$ & $\mathbf{0 . 7 3} \pm \mathbf{0 . 0 4}-\mathbf{0 . 6 0} \pm \mathbf{0 . 0 3}=\mathbf{0 . 1 3} \pm \mathbf{0 . 0 7}$ & $\mathbf{- 0 . 1 3} \pm \mathbf{0 . 0 4}$ \\
Summer relaxation & $\mathbf{1 8}-\mathbf{2 2}$ Jul & $\mathbf{0 . 3 9} \pm \mathbf{0 . 0 4}-\mathbf{0 . 4 2} \pm \mathbf{0 . 0 2}=\mathbf{- 0 . 0 3} \pm \mathbf{0 . 0 6}$ & $\mathbf{- 0 . 0 4} \pm \mathbf{0 . 0 2}$ \\
Weak summer upwelling & 22-26 Jul & $0.14 \pm 0.03-0.39 \pm 0.04=-\mathbf{0 . 2 5} \pm \mathbf{0 . 0 6}$ & $\mathbf{- 0 . 1 6} \pm \mathbf{0 . 0 3}$ \\
Autumn downwelling & 17-19 Sep & $-0.10 \pm 0.02-0.11 \pm 0.01=-\mathbf{0 . 2 1} \pm \mathbf{0 . 0 3}$ & $\mathbf{- 0 . 0 2} \pm \mathbf{0 . 0 2}$ \\
Autumn transition & $\mathbf{1 9 - 2 3}$ Sep & $\mathbf{0 . 0 2} \pm \mathbf{0 . 0 2}-\mathbf{0 . 1 7} \pm \mathbf{0 . 0 2}=\mathbf{- 0 . 1 5} \pm \mathbf{0 . 0 4}$ & $\mathbf{0 . 0 7} \pm \mathbf{0 . 0 2}$ \\
Autumn upwelling & 23-26 Sep & $0.01 \pm 0.02-0.11 \pm 0.02=\mathbf{- 0 . 0 3} \pm \mathbf{0 . 0 2}$ & $\mathbf{- 0 . 1 0} \pm \mathbf{0 . 0 4}$ \\
\hline
\end{tabular}


ration rates, perhaps because the lag time between ingestion and respiration processes is likely to occur in the microheterotroph community. In addition, the grazing rates measure the instantaneous changes in chlorophyll or carbon concentrations and the respiration rates are influenced by previous processes.

The geochemical approach avoids most of the problems associated with in vitro methods and, although box-model estimations involve large potential errors in the estimation of the NEP of N-nutrients, DON and $\mathrm{PON}$, it is a unique method to measure the ecosystem metabolism directly (Smith \& Hollibaugh 1997). Although box-model estimations are less accurate than in vitro techniques, the resultant values are ready for direct interpretation at the ecosystem level. The deficits of the geochemical approach are linked to the fact that the specific processes that occur in the study system cannot be identified, i.e. only the net result of the processes taking place inside the box is known. However, accumulation and losses, a relevant component of the metabolic balance of any transient ecosystem (Piedracoba et al. 2008), omitted by the in vitro approach, can be evaluated.

The high grazing rates provoke disagreements between the in vitro approach in this paper and the in situ approach of Piedracoba et al. (2008) to assess the metabolic status of the ría. Considering the advantages of both methods, we can conclude that they are complementary, and that their simultaneous application allowed us to obtain a better understanding of how the system operates. The in situ approach defines the metabolic state of the system and the in vitro approach shows the relative importance of the variety of metabolic processes that occur in the Ría de Vigo.

Acknowledgements. We thank the members of the Department of Oceanography of the Instituto de Investigacións Mariñas (CSIC) and the Group of Physical Oceanography of the University of Vigo who participated in this cruise. This work would not have been possible without the cooperation of the captain, crew and technicians of RV 'Mytilus'. We are also grateful to E. A. Fanjul and B. Morón (Puertos del Estado) for the meteorological data of the Silleiro buoy. Financial support for this work came from the Spanish Ministerio de Educación y Ciencia (MEC) grant nos. REN2000-0880-C02-01 and -02 MAR, and the Xunta de Galicia grant no. PGIDT01MAR40201PN. S.P. and M.N.-C. received MEC fellowships and CSIC-I3P postgraduate fellowships and I.G.T. received a predoctoral fellowship from the Portuguese FCT. This is contribution no. 41 of the Unidad Asociada GOFUVI-CSIC.

\section{LITERATURE CITED}

Álvarez-Salgado XA, Rosón G, Pérez FF, Figueiras FG, Pazos Y (1996) Nitrogen cycling in an estuarine upwelling system, the Ría de Arousa (NW Spain). I. Short-time-scale patterns of hydrodynamic and biogeochemical circulation. Mar Ecol Prog Ser 135:259-273

Álvarez-Salgado XA, Nieto-Cid M, Piedracoba S, Crespo BG and 8 others (2005) Origin and fate of a bloom of Skeletonema costatum during a winter upwelling/downwelling sequence in the Ría de Vigo (NW Spain). J Mar Res 63: 1127-1149

Bode A, Varela M (1998) Mesoscale estimations of primary production in shelf waters: a case study in the Golfo Artrabo (NW Spain). J Exp Mar Biol Ecol 229:111-131

Bode A, Varela M, Barquero S, Álvarez-Osorio MT, González N (1998) Preliminary studies on the export of organic matter during phytoplankton blooms off La Coruña (North Western Spain). J Mar Biol Ass UK 78:1-15

Calbet A, Landry MR (2004) Phytoplankton growth, microzooplankton grazing and carbon 15 cycling in marine systems. Limnol Oceanogr 49:51-57

Fermín EG, Figueiras FG, Arbones B, Villarino ML (1996) Short-time scale development of a Gymnodinium catenatum population in the Ría de Vigo (NW Spain). J Phycol 32: 212-221

Figueiras FG, Jones KJ, Mosquera AM, Álvarez-Salgado XA, Edwards A, MacDougall N (1994) Red tide assemblage formation in an estuarine upwelling ecosystem: Ría de Vigo. J Plankton Res 16:857-878

Fileman E, Burkill P (2001) The herbivorous impact of microzooplankton during two short-term Lagrangian experiments off the NW coast of Galicia in summer 1998. Prog Oceanogr 51:361-383

Fraga F (1976) Fotosíntesis en la Ría de Vigo. Invest Pesq 40 : 151-167

Fraga F, Ríos AF, Pérez FF, Figueiras FG (1998) Theoretical limits of oxygen:carbon and oxygen:nitrogen ratios during photosynthesis and mineralization of organic matter in the sea. Sci Mar 62:161-168

Gallegos CL (1989) Microzooplankton grazing on phytoplankton in Rhode River, Maryland: nonlinear feeding kinetics. Mar Ecol Prog Ser 57:23-33

Gardner WD (1980a) Sediment trap dynamics and calibration: a laboratory evaluation. J Mar Res 38:17-39

Gardner WD (1980b) Field assessment of sediment traps. J Mar Res 38:41-52

Jeffrey SW, Wright SW (2006) Photosynthetic pigments in marine microalgae: insights from cultures and the sea. In: Subba Rao DV (ed) Algal cultures, analogues of blooms and applications. Science Publishers, Enfield, p 33-90

Knauer GA, Martin JH, Bruland KW (1979) Fluxes of particulate carbon, nitrogen and phosphorous in the upper water column of the northeast Pacific. Deep-Sea Res 26:97-108

Landry MR, Hassett RP (1982) Estimating the grazing impact of marine micro-zooplankton. Mar Biol 67:283-288

Moncoiffé G, Álvarez-Salgado XA, Figueiras FG, Savidge G (2000) Seasonal and short-time-scale dynamics of microplankton community production and respiration in an inshore upwelling system. Mar Ecol Prog Ser 196:111-126

Nieto-Cid M, Álvarez-Salgado XA, Gago J, Pérez FF (2005) DOM fluorescence, a tracer for biogeochemical processes in a coastal upwelling system (NW Iberian Peninsula). Mar Ecol Prog Ser 297:33-50

Nogueira E, Ibanez F, Figueiras FG (2000) Effect of meteorological and hydrographic disturbances on the microplankton community structure in the Ría de Vigo (NW Spain). Mar Ecol Prog Ser 203:23-45

Olli K, Riser CW, Wassmann P, Ratkova T, Arashkevich E, Pasternak A (2001) Vertical flux of biogenic matter during a Lagrangian study off the NW Spanish continental margin. Prog Oceanogr 51:443-466

Piedracoba S, Nieto-Cid M, Souto C, Gilcoto M, Rosón G, Álvarez-Salgado XA, Varela R, Figueiras FG (2008) Physical-biological coupling in the coastal upwelling system of 
the Ría de Vigo (NW Spain). I: In situ approach. Mar Ecol Prog Ser 353:27-40

Porter KG, Feig YS (1980) The use of DAPI for identifying and counting aquatic microflora. Limnol Oceanogr 25:943-948

Putt M, Stoecker DK (1989) An experimental determined carbon: volume ratio for marine 'oligotrichous' ciliates from estuarine and coastal waters. Limnol Oceanogr 34: 1097-1103

Quiñones RA, Platt T (1991) The relationship between the f-ratio and the P:R ratio in the pelagic ecosystem. Limnol Oceanogr 36:211-213

Richardson TL, Cullen JJ (1995) Changes in buoyancy and chemical composition during growth of a coastal marine diatom: ecological and biogeochemical consequences. Mar Ecol Prog Ser 128:77-99

Riebesell U (1989) Comparison of sinking and sedimentation rate measurements in a diatom winter/spring bloom. Mar Ecol Prog Ser 54:109-119

Sherr EB, Sherr BF (1998) Role of microbes in pelagic food webs: a revised concept. Limnol Oceanogr 33:1225-1227

Smayda TJ (1970) The suspension and sinking of phytoplankton in the sea. Oceanogr Mar Biol Annu Rev 8:353-414

Smith SV, Hollibaugh JT (1993) Coastal metabolism and the oceanic organic carbon balance. Rev Geophys 31:75-89

Smith SV, Hollibaugh JT (1997) Annual cycle an interannual variability of ecosystem metabolism in a temperate climate embayment. Ecol Monogr 67:509-533

Strathmann R (1967) Estimating the organic carbon content of phytoplankton from cell volume or plasma volume. Limnol Oceanogr 12:411-418

Strickland JDH, Parsons TR (1972) A practical handbook of seawater analysis, 2nd edn. Bull Fish Res Board Can 167

Teira E, Abalde J, Álvarez-Ossorio MT, Bode A and 7 others (2003) Plankton carbon budget in a coastal wind-driven upwelling station off A Coruña (NW Iberian Peninsula). Mar Ecol Prog Ser 265:31-43

Editorial responsibility: Otto Kinne (Editor-in-Chief), Oldendorf/Luhe, Germany
Tilstone GH, Figueiras FG, Fermín EG, Arbones B (1999) Significance of nanophytoplankton photosynthesis and primary production in a coastal upwelling system (Ría de Vigo, NW Spain). Mar Ecol Prog Ser 183:13-27

Torres-López S, Álvarez-Salgado XA, Varela RA (2005) Offshore export versus in situ fractionated mineralization: a 1-D model of the fate of the primary production of the Rías Baixas (Galicia, NW Spain). J Mar Sys 54:175-193

UNESCO (1985) The international system of units (SI) in oceanography. UNESCO Tech Pap Mar Sci 45:1-124

UNESCO (1994) Protocols for the Joint Global Ocean Flux Study (JGOFS) core measurements. Manuals and guide, no. 29. Intergovernmental Oceanographic Commission, Paris

Utermöhl H (1958) Zur Vervollkommnung der quantitativen Phytoplankton-Methodik. Mitt Int Ver Theor Angew Limnol 9:1-38

Varela MM, Bode A, Gonzalez N, Rodriguez C, Varela M (2003) Fate of organic matter in the Ria de Ferrol (Galicia, NW Spain): uptake by pelagic bacteria vs. particle sedimentation. Acta Oecol 24:77-86

Varela M, Prego R, Pazos Y (2004) Vertical biogenic particle flux in a western Galician ria (NW Iberian Peninsula). Mar Ecol Prog Ser 269:17-24

Varela M, Prego R, Pazos Y, Moroño A (2005) Influence of upwelling and river runoff interaction on phytoplankton assemblages in a middle Galician ria and comparison with northern and southern rias (NW Iberian Peninsula). Estuar Coast Shelf Sci 64:721-737

Verity PG, Robertson CY, Tronzo CR, Andrews MG, Nelson JR, Sieracki ME (1992) Relationships between cell volume and the carbon and nitrogen content of marine photosynthetic nanoplankton. Limnol Oceanogr 37: 1434-1446

Waite A, Bienfang PK, Harrison PJ (1992) Spring bloom sedimentation in a subarctic ecosystem. II. Succession and sedimentation. Mar Biol 114:131-138

Submitted: October 10, 2006; Accepted: July 30, 2007

Proofs received from author(s): December 21, 2007 